\title{
Abnormal Cells to Total Cells Ratio Measurement
}

National Cancer Institute

\section{Source}

National Cancer Institute. Abnormal Cells to Total Cells Ratio Measurement. NCI

Thesaurus. Code C150835.

The determination of the ratio of abnormal cells compared to total cells present in a sample. The measurement may be expressed as a ratio or percentage. 